\title{
Nalmefene Induced Elevation in Serum Prolactin in Normal Human Volunteers: Partial Kappa Opioid Agonist Activity?
}

\author{
Gavin Bart",', James H Schluger', Lisa Borg', Ann Ho', Jean M Bidlack² and Mary Jeanne Kreek' \\ 'The Laboratory of the Biology of Addictive Diseases, The Rockefeller University, New York, NY, USA; ' Department of Pharmacology and \\ Physiology, University of Rochester School of Medicine and Dentistry, Rochester, NY, USA
}

\begin{abstract}
In humans, mu- and kappa-opioid receptor agonists lower tuberoinfundibular dopamine, which tonically inhibits prolactin release. Serum prolactin is, therefore, a useful biomarker for tuberoinfundibular dopamine. The current study evaluated the unexpected finding that the relative mu- and kappa-opioid receptor selective antagonist nalmefene increases serum prolactin, indicating possible kappa-opioid receptor agonist activity. In all, 33 healthy human volunteers ( 14 female) with no history of psychiatric or substance use disorders received placebo, nalmefene $3 \mathrm{mg}$, and nalmefene $10 \mathrm{mg}$ in a double-blind manner. Drugs were administered between 0900 and 1000 on separate days via 2-min intravenous infusion. Serial blood specimens were analyzed for serum levels of prolactin. Additional in vitro studies of nalmefene binding to cloned human kappa-opioid receptors transfected into Chinese hamster ovary cells were performed. Compared to placebo, both doses of nalmefene caused significant elevations in serum prolactin $(p<0.002$ for nalmefene 3 mg and $p<0.0005$ for nalmefene $10 \mathrm{mg}$ ). There was no difference in prolactin response between the 3 and $10 \mathrm{mg}$ doses. Binding assays confirmed nalmefene's affinity at kappa-opioid receptors and antagonism of mu-opioid receptors. $\left[{ }^{35} \mathrm{~S}\right] \mathrm{GTP} \gamma \mathrm{S}$ binding studies demonstrated that nalmefene is a full antagonist at mu-opioid receptors and has partial agonist properties at kappa-opioid receptors. Elevations in serum prolactin following nalmefene are consistent with this partial agonist effect at kappa-opioid receptors. As kappaopioid receptor activation can lower dopamine in brain regions important to the persistence of alcohol and cocaine dependence, the partial kappa agonist effect of nalmefene may enhance its therapeutic efficacy in selected addictive diseases.
\end{abstract}

Neuropsychopharmacology (2005) 30, 2254-2262. doi:I0. I038/sj.npp. I 3008 I I; published online 29 June 2005

Keywords: nalmefene; opioid antagonist; kappa opioid; dopamine; prolactin

\section{INTRODUCTION}

Three opioid antagonists, naloxone, naltrexone, and nalmefene, are currently approved for human use. Naloxone and nalmefene have been approved for parenteral administration and are used in the reversal of opioid (eg heroin) overdose. Naltrexone is available for oral administration and is approved for the treatment of opioid and alcohol dependence. Naltrexone's effectiveness is poor for the former and moderate for the latter (San et al, 1991; Volpicelli et al, 1992; O'Malley et al, 1992, 2002). Nalmefene also has a moderate treatment effect for alcoholism but is not yet available for this indication (Mason et al, 1994; Anton et al, 2004).

Naloxone, naltrexone, and nalmefene are moderately selective ligands for the three opioid receptor subtypes

*Correspondence: Dr G Bart, The Laboratory of the Biology of Addictive Diseases, The Rockefeller University, 1230 York Avenue, New York, NY I0021, USA, Tel: + I 212327 8282, Fax: + I 212327 7023, E-mail: bartg@rockefeller.edu

Received 4 November 2004; revised 16 May 2005; accepted 17 May 2005

Online publication: I June 2005 at http://www.acnp.org/citations/ Npp060 105040520/default.pdf (mu, kappa, and delta). While in the rat each antagonist has highest affinity for mu-opioid receptors, in non-human primates and humans they have similar affinity at mu- and kappa-opioid receptors followed by much lower affinity at delta-opioid receptors (Michel et al, 1985; Raynor et al, 1994; Emmerson et al, 1994; Toll et al, 1998). Respective reported $K_{\mathrm{i}}(\mathrm{nM})$ values for naloxone, naltrexone, and nalmefene at cloned human receptors expressed on Chinese hamster ovary (CHO) cells are: 1.4 at mu, 2.5 at kappa, and 67.5 at delta; 0.2 at mu, 0.4 at kappa, and 10.8 at delta; and 0.3 at mu, 0.3 at kappa, and 7.3 at delta (Toll et al, 1998). These values are not dissimilar to those measured by Emmerson et al (1994), using monkey brain cortex homogenates.

To date, data from receptor binding studies have demonstrated that naloxone, naltrexone, and nalmefene are primarily mu-opioid receptor antagonists; however, there have been a few reports suggesting that nalmefene may also have agonist, or partial agonist properties at kappa-opioid receptors. For example, nalmefene has been shown to stimulate $\left[{ }^{35} \mathrm{~S}\right] \mathrm{GTP} \gamma \mathrm{S}$ binding to a level of approximately $20 \%$ above baseline (compared to a level of approximately $75 \%$ for cyclazocine, a predominantly kappa agonist with mu partial agonism) in a C6 glioma cell 
membrane preparation expressing human kappa-opioid receptors, although another study showed no effect on $\left[{ }^{35} \mathrm{~S}\right] \mathrm{GTP} \gamma \mathrm{S}$ binding in $\mathrm{CHO}$ cells compared to U69,593 (a full kappa agonist) stimulation (Toll et al, 1998; Remmers et al, 1999). In vivo work also suggests that nalmefene has kappa activity. These reports include ethylketocyclazocinelike discrimination (a sign of kappa agonist effect) in rhesus monkeys following nalmefene infusion (Woods et al, 1986) and increased food intake (an effect associated with kappa agonism) in mice following chronic oral nalmefene administration (Chen et al, 2004).

In humans, prolactin is secreted from the anterior pituitary and is primarily regulated through tonic inhibition by tuberoinfundibular dopaminergic (TIDA) neurons (Freeman et al, 2000). Dopamine from TIDA neurons acts at dopamine D2 receptors present on pituitary lactotrophs to inhibit prolactin release (Freeman et al, 2000). The endogenous opioid system, more specifically mu- and kappa-opioid receptors localized on dopaminergic neurons within the mesolimbic-mesocortical and TIDA systems, modulates dopamine release. Therefore, serum prolactin may also serve as a biomarker of opioid effects on TIDA (NIH Definitions Working Group, 2000). Human studies have shown that the mu-opioid receptor agonist methadone and the kappa-opioid receptor agonist dynorphin A(1-13) each stimulate prolactin release; and non-human primate and human studies have shown that the increase in serum prolactin following acute administration of mu- and kappaopioid agonists is blocked by administration of an opioid antagonist (Kreek, 1978; Wehrenberg et al, 1981; Pfeiffer et al, 1986; VanVugt et al, 1989a; Ur et al, 1997; Kreek et al, 1999). While mu- and kappa-opioid antagonists have generally been shown to have no effect on serum prolactin, there are conflicting data in females indicating that prolactin response to these antagonists may be affected by menstrual cycle phase (Ellingboe et al, 1980; Mendelson et al, 1986; VanVugt et al, 1989b; Butelman et al, 1999; Mello et al, 2000).

Based on our observation in humans that nalmefene may cause elevations in serum prolactin (unpublished data), the current study was conducted to explore the possible kappaopioid agonist effects of nalmefene by conducting a doseresponse study in healthy humans. As nalmefene shows binding affinity to mu- and kappa-opioid receptors similar to naloxone, and we have not observed alterations in serum prolactin following naloxone $30 \mathrm{mg}$ intravenously (unpublished data), an increase in serum prolactin following nalmefene may indicate that, unlike naloxone, nalmefene has agonist or partial agonist properties at kappa-opioid receptors. To further assess the possibility that nalmefene has kappa-agonist properties, binding studies and measures of $\left[{ }^{35} \mathrm{~S}\right] \mathrm{GTP} \gamma \mathrm{S}$ activity were performed in $\mathrm{CHO}$ cells stably expressing cloned human kappa-opioid receptors.

\section{METHODS}

\section{Subjects}

The study was approved by the Institutional Review Board of the Rockefeller University Hospital General Clinical Research Center (NIH-GCRC) and performed in accordance with the Helsinki Declaration of 1975. Written informed consent was obtained prior to participation; confidentiality was strictly maintained. Nalmefene $\mathrm{HCl} 1 \mathrm{mg} / \mathrm{ml}$ (Revix) was purchased from Baxter Health Care (Deerfield, IL) and its administration was conducted under Investigational New Drug status (held by Mary Jeanne Kreek, MD, The Rockefeller University) approved by the United States Food and Drug Administration. The study cohort consisted of 33 subjects (14 female) with a mean age of 34.6 years (range 19-59 years; SD 10.3 years). The mean age of the male subjects was 34.4 years (range 19-59 years; SD 10.5 years) and the mean age of the female subjects was 34.9 years (range 19-52 years; SD 10.4 years). Menstrual cycle phase data were not available.

Healthy normal volunteers were recruited from the local community by word of mouth and by advertisement. Subjects were initially screened for the study by phone contact with a registered nurse. Evaluation for medical and psychiatric inclusion and exclusion criteria were made by an internist or psychiatrist using clinical interview, physical exam, and review of laboratory and corroborative data. Evaluations included general medical, psychiatric, and substance abuse histories, physical examination, ECG, and laboratory testing including complete blood cell count, metabolic panel, thyroid function tests, and urinalysis. Subjects were counseled about, and gave informed consent for, HIV testing. Urine was collected on each of the outpatient visits and on a 24-h basis during inpatient studies. Aliquots of urine were tested daily, both during the screening process and during the inpatient stay, for the presence of opioids, cocaine, cannabinoids, or benzodiazepines. Subjects included in the study were free of significant medical problems, were HIV antibody negative, were not pregnant (serum beta-hCG confirmation upon admission), did not meet DSM IV criteria for any axis I diagnosis such as schizophrenia, major depression, bipolar disorder, panic disorder, PTSD, or generalized anxiety disorder, and substance and/or alcohol abuse or dependence. Eight subjects who were current smokers all smoked $<1$ pack per day and none met DSM IV criteria for nicotine dependence. Female subjects were not on hormone replacement therapy or using hormonal contraceptives. Subjects were not taking prescription medications, and were not regularly using over-the-counter medications or herbal preparations.

\section{Inpatient Studies}

Subjects were admitted to the in-patient unit at least one evening prior to the testing days. In most cases, testing was completed on 3 consecutive days, and in some cases, testing was carried out during separate, closely scheduled admissions to accommodate time constraints of subjects. Subjects fasted at least $9 \mathrm{~h}$ prior to the beginning of testing and were allowed to eat only after the first $2 \mathrm{~h}$ of testing had elapsed. Test substances were administered through, and blood was withdrawn from, an indwelling 20-G intravenous catheter (BD Angiocath Autoguard, Becton, Dickinson and Company, New Jersey), inserted at least an hour prior to the beginning of testing. In some cases, a functioning catheter from the previous day was used. Total blood volume sampled, including that taken during screening and testing, did not exceed $550 \mathrm{ml}$. In a random order double-blind 
manner, nalmefene $10 \mathrm{mg}$, nalmefene $3 \mathrm{mg}$, or saline placebo was administered intravenously over $2 \mathrm{~min}$ in a volume of $10 \mathrm{ml}$. Each subject served as his or her own control receiving a placebo, and each of the two doses of nalmefene, on separate days.

At several intervals (just prior to each blood draw, described below) on each test day, all subjects completed two $100 \mathrm{~mm}$ visual analog scales (VAS) related to mood (anchors terrible and terrific) and drug effect (anchors sick and euphoria).

\section{Prolactin Assay}

Serum prolactin levels were determined in blood samples drawn at sequential time points. Time points started $10 \mathrm{~min}$ prior to test substance administration, at time zero (immediately prior to test substance administration), and then at $10,20,30,40,50,60,75,90,120$, and $240 \mathrm{~min}$ following nalmefene or placebo administration. Blood was drawn into plain vacutainers, and immediately placed on ice. Samples were stored on ice for up to $40 \mathrm{~min}$ until centrifuged at $4{ }^{\circ} \mathrm{C}$ at $1500 \mathrm{~g}$ for $5 \mathrm{~min}$. Serum was then removed, aliquoted, and stored at $-40^{\circ} \mathrm{C}$ until assayed. Serum prolactin levels were determined by IRMA procedures, with slight modifications (ICN, Pharmaceuticals Inc., Orangeburg, NY). Prolactin analytical range was 2.5-100 ng/ $\mathrm{ml}$ and intra- and interassay coefficients of variation were 8.6 and $14.3 \%$, respectively.

\section{Estradiol Assay}

Estradiol was measured at a single time point (generally in the morning) as part of admission laboratory screening. Blood was drawn into plain vacutainers and sent to the clinical laboratories of Memorial Sloan-Kettering Cancer Center for evaluation within $2 \mathrm{~h}$ of sampling. Serum estradiol levels were determined by magnetic separation assay (Estradiol (ES2), Bayer Immuno 1 System, Bayer Corporation, Tarrytown, NY). Estradiol analytical range was $5-3600 \mathrm{pg} / \mathrm{ml}$ and intra- and interassay coefficients of variation were 5.3 and $7.7 \%$, respectively.

\section{Statistics}

Statistical analyses of serum prolactin response was performed using area under the curve (AUC) from 0 to $90 \mathrm{~min}$ after each dose of nalmefene or placebo administration, to focus on the main effects of nalmefene and to minimize the influence of other factors such as enterohepatic recycling, which may have occurred later in the studies when subjects were allowed to have their first meal. To examine the effects of nalmefene $10 \mathrm{mg}$ and nalmefene $3 \mathrm{mg}$, compared with placebo, two-way analysis of variance (ANOVA), Condition by Gender, followed by NewmanKeuls post hoc tests was also used to evaluate the differences between conditions and any possible effect of gender.

\section{Binding Studies}

CHO cells stably transfected with the human delta- and kappa-opioid receptors were obtained from Dr Larry Toll (SRI International, Palo Alto, CA, USA); human mu-opioid receptors were obtained from $\mathrm{Dr}$ George Uhl (NIDA Intramural Program, Bethesda, MD, USA). The cells were grown in $100 \mathrm{~mm}$ dishes in Dulbecco's modified Eagle's media supplemented with $10 \%$ fetal bovine serum (FBS) and penicillin-streptomycin $(10000 \mathrm{U} / \mathrm{ml})$ at $37^{\circ} \mathrm{C}$ in a $5 \%$ $\mathrm{CO}_{2}$ atmosphere. The affinity and selectivity of the compounds for the multiple opioid receptors was determined by incubating the membranes with radiolabeled ligands and 12 different concentrations of the compounds at $25^{\circ} \mathrm{C}$ in a final volume of $1 \mathrm{ml}$ of $50 \mathrm{mM}$ Tris- $\mathrm{HCl}, \mathrm{pH}$ 7.5. Incubation times of $60 \mathrm{~min}$ were used for the mu-opioid receptor selective peptide $\left[{ }^{3} \mathrm{H}\right] \mathrm{DAMGO}$ and the kappaopioid receptor selective ligand $\left[{ }^{3} \mathrm{H}\right] \mathrm{U} 69,593$. A $3-\mathrm{h}$ incubation was used with the delta-opioid receptor selective antagonist $\left[{ }^{3} \mathrm{H}\right]$ naltrindole. To determine the $\mathrm{IC}_{50}$ values for the inhibition of binding by the compounds, the final concentrations of $\left[{ }^{3} \mathrm{H}\right]$ DAMGO, $\left[{ }^{3} \mathrm{H}\right]$ naltrindole, and $\left[{ }^{3} \mathrm{H}\right] \mathrm{U} 69,593$ were $0.25,0.2$, and $1 \mathrm{nM}$, respectively. Nonspecific binding was measured by inclusion of $10 \mu \mathrm{M}$ naloxone. Binding was terminated by filtering the samples through Schleicher \& Schuell No. 32 glass fiber filters (Keene, NH, USA) using a Brandel 48-well cell harvester. Filters were soaked for at least $60 \mathrm{~min}$ in $0.25 \%$ polyethylenimine for $\left[{ }^{3} \mathrm{H}\right]$ naltrindole and $\left[{ }^{3} \mathrm{H}\right] \mathrm{U} 69,593$ binding experiments. After filtration, filters were washed three times with $3 \mathrm{ml}$ of cold $50 \mathrm{mM}$ Tris- $\mathrm{HCl}, \mathrm{pH} 7.5$, and were counted in $2 \mathrm{ml}$ of Ecoscint A scintillation fluid. The $K_{\mathrm{i}}$ values of unlabeled compounds were calculated from the equation $K_{\mathrm{i}}=\mathrm{IC}_{50} /(1+S)$, where $S=$ (concentration of radioligand) $/$ ( $K_{\mathrm{d}}$ of radioligand) (Cheng and Prusoff, 1973).

\section{$\left[{ }^{35} \mathrm{~S}\right] \mathrm{GTP} \gamma \mathrm{S}$ Binding Studies}

Membranes from $\mathrm{CHO}$ cells stably expressing either human kappa- or mu-opioid receptors were used in the experiments. Cells were scraped from tissue culture plates, and then centrifuged at $1000 \mathrm{~g}$ for $10 \mathrm{~min}$ at $4^{\circ} \mathrm{C}$. The cells were resuspended in phosphate-buffered saline, $\mathrm{pH} 7.4$, containing $0.04 \%$ EDTA. After centrifugation at $1000 \mathrm{~g}$ for $10 \mathrm{~min}$ at $4^{\circ} \mathrm{C}$, the cell pellet was resuspended in membrane buffer, which consisted of $50 \mathrm{mM}$ Tris- $\mathrm{HCl}, 3 \mathrm{mM} \mathrm{MgCl}$, and $1 \mathrm{mM}$ EGTA, pH 7.4. The membranes were homogenized with a Dounce homogenizer, followed by centrifugation at $40000 \mathrm{~g}$ for $20 \mathrm{~min}$ at $4^{\circ} \mathrm{C}$. The membrane pellet was resuspended in membrane buffer and the centrifugation step was repeated. The membranes were then resuspended in assay buffer, which consisted of $50 \mathrm{mM}$ Tris- $\mathrm{HCl}, 3 \mathrm{mM} \mathrm{MgCl}, 100 \mathrm{mM}$ $\mathrm{NaCl}$, and $0.2 \mathrm{mM}$ EGTA, $\mathrm{pH}$ 7.4. The protein concentration was determined by the Bradford assay (Bradford, 1976) using bovine serum albumin as the standard. The membranes were frozen at $-80^{\circ} \mathrm{C}$ until use.

$\mathrm{CHO}$ cell membranes expressing either the human kappaopioid receptor $(15 \mu \mathrm{g}$ of protein per tube) or mu-opioid receptor $(7.5 \mu \mathrm{g}$ of protein per tube) were incubated with 12 different concentrations of the agonist (ie DAMGO or $\mathrm{U} 50,488$ ) in assay buffer for $60 \mathrm{~min}$ at $30^{\circ} \mathrm{C}$ in a final volume of $0.5 \mathrm{ml}$. The reaction mixture contained $3 \mu \mathrm{M}$ GDP and 80 pmol $\left[{ }^{35} \mathrm{~S}\right] \mathrm{GTP} \gamma \mathrm{S}$. Basal activity was determined in the presence of $3 \mu \mathrm{M}$ GDP and in the absence of an agonist, and nonspecific binding was determined in the presence of $10 \mu \mathrm{M}$ unlabeled GTP $\gamma \mathrm{S}$. Then, the membranes were filtered onto glass fiber filters by vacuum filtration, followed by 
three washes with $3 \mathrm{ml}$ ice-cold $50 \mathrm{mM}$ Tris- $\mathrm{HCl}, \mathrm{pH}$ 7.5. Samples were counted in $2 \mathrm{ml}$ Ecoscint A scintillation fluid. Data represent the percent of agonist stimulation $\left[{ }^{35} \mathrm{~S}\right] \mathrm{GTP} \gamma \mathrm{S}$ binding over the basal activity, defined as: $(($ specific binding/basal binding $) \times 100)-100$. All experiments were repeated at least three times, and were performed in triplicate. To determine antagonist activity of a compound at the mu-opioid receptor, $\mathrm{CHO}$ membranes expressing mu-opioid receptors were incubated with the compound in the presence of $200 \mathrm{nM}$ of the mu-opioid receptor agonist DAMGO. To determine antagonist activity of a compound at the kappa-opioid receptor, $\mathrm{CHO}$ membranes expressing kappa-opioid receptors were incubated with the compound in the presence of $100 \mathrm{nM}$ of the kappa-opioid receptor agonist U50,488.

\section{RESULTS}

\section{Subjective Effects of Nalmefene}

VAS measures of mood and drug effect did not reveal any significant findings related to nalmefene. However, upon asking subjects several hours after the completion of testing 'how did the study go?', two subjects provided information about feeling 'dream-like' following nalmefene.

\section{Prolactin Dose Response to Nalmefene}

Dose-response curves showing all mean $( \pm$ SEM) prolactin measurements from $0 \mathrm{~min}$ before to $240 \mathrm{~min}$ after each nalmefene dose $(0,3$, and $10 \mathrm{mg})$ are shown in Figure 1a. AUCs of serum prolactin from 0 to $90 \mathrm{~min}$ after administration of nalmefene are shown in Figure 1b. ANOVA of nalmefene dose $(0,3$, and $10 \mathrm{mg})$ by gender showed a significant main effect of dose, $\mathrm{F}(2,62)=9.78, p<0.0002$, but no effect of gender, $\mathrm{F}(1,31)<1$. Newman-Keuls post hoc tests showed that prolactin following each dose of nalmefene was greater than placebo (nalmefene $3 \mathrm{mg}$ $p<0.002$; nalmefene $10 \mathrm{mg} p<0.0005$ ), but there was no difference between nalmefene 3 and $10 \mathrm{mg}$.

Although there was no effect of gender on prolactin response, a regression analysis of estradiol effects on prolactin response was performed in a subset of five female subjects for whom serum estradiol levels were available. There was the expected correlation between basal estradiol and prolactin following placebo $(r=0.947, p<0.02)$. However, the change in prolactin AUC following nalmefene $10 \mathrm{mg}$ from baseline was not correlated with basal estradiol (see Figure 2).

\section{Radiolabeled Receptor Binding Assay}

The affinity and selectivity of nalmefene for mu- delta-, and kappa-opioid receptors was determined by the use of tritiated receptor binding assays. Membranes from $\mathrm{CHO}$ cells that stably expressed either the human mu- delta-, or kappa-opioid receptors were incubated with 12 different concentrations of nalmefene. Table 1 shows that nalmefene had high affinity for both mu- and kappa-opioid receptors. Nalmefene had a three-fold greater affinity for kappa- than mu-opioid receptors, and a 200 -fold greater affinity for kappa- than delta-opioid receptors.
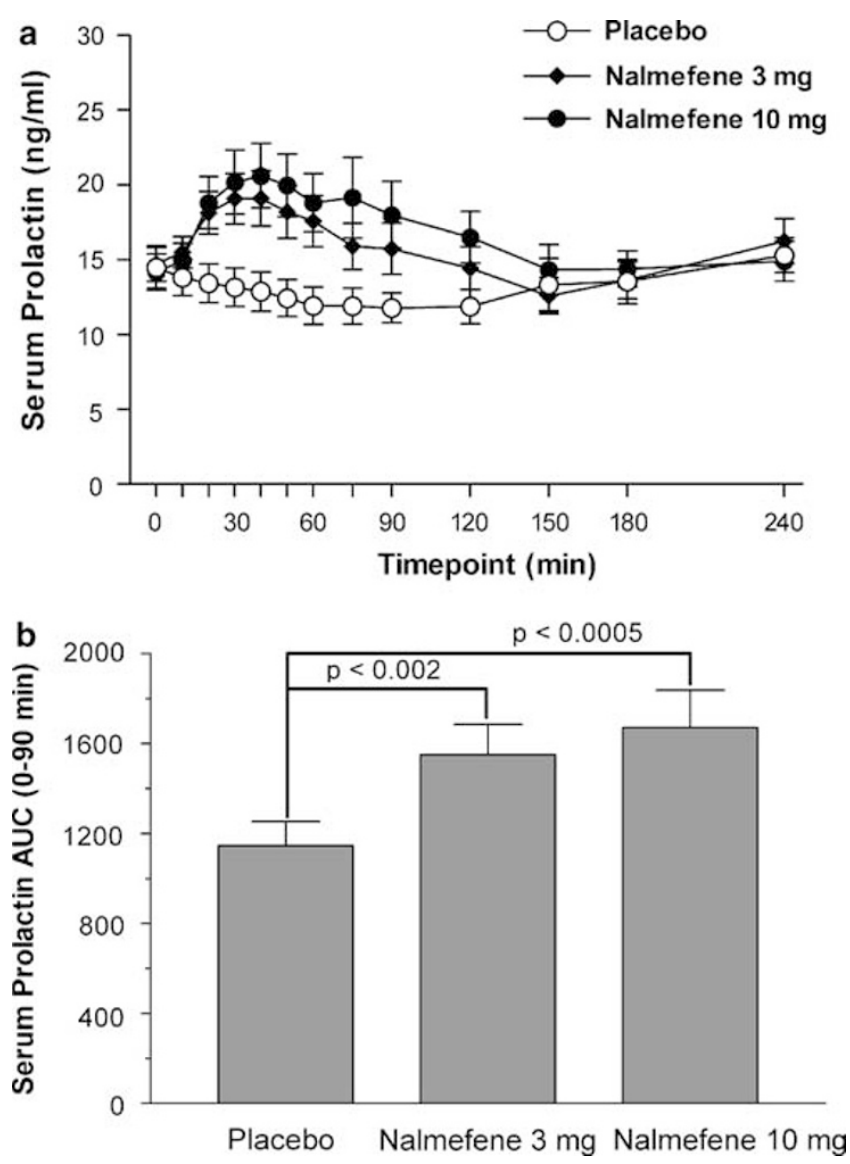

Figure I (a) Mean $( \pm$ SEM) level of serum prolactin at each time point from 0 to $240 \mathrm{~min}$ after each dose of nalmefene infusion $(n=33)$. (b) Dose response of serum prolactin measured as AUC from 0 to 90 min after each infusion. Values are shown as mean \pm SEM. There were significant increases in serum prolactin after both $3 \mathrm{mg}(p<0.002)$ and $10 \mathrm{mg}(p<0.0005)$ doses of nalmefene, but there was no difference between the 3 and $10 \mathrm{mg}$ doses.

\section{$\left[{ }^{35} \mathrm{~S}\right] \mathrm{GTP} \gamma \mathrm{S}$ Binding to Determine the Efficacy of Nalmefene at Mu-Opioid Receptors}

In order to determine if nalmefene was an agonist, antagonist, or mixed agonist/antagonist at mu-opioid receptors, $\mathrm{CHO}$ cell membranes that expressed mu-opioid receptors were incubated with 12 different concentrations of nalmefene in the presence of $\left[{ }^{35} \mathrm{~S}\right] \mathrm{GTP} \gamma \mathrm{S}$. As shown in Figure 3a, nalmefene did not stimulate $\left[{ }^{35} \mathrm{~S}\right] \mathrm{GTP} \gamma \mathrm{S}$ binding mediated by the mu-opioid receptor. Figure $3 \mathrm{~b}$ shows that nalmefene inhibited $\left[{ }^{35} S\right] \mathrm{GTP} \gamma \mathrm{S}$ binding that was induced by the mu-opioid receptor selective peptide DAMGO. Nalmefene had an $I_{\max }$ value of $91 \pm 3.7 \%$ and an $\mathrm{IC}_{50}$ value of $13 \pm 2.3 \mathrm{nM}$. Thus, nalmefene was an antagonist at the mu-opioid receptor.

\section{$\left[{ }^{35} \mathrm{~S}\right] \mathrm{GTP} \gamma \mathrm{S}$ Binding to Determine the Efficacy of Nalmefene at Kappa-Opioid Receptors}

In order to determine if nalmefene was an agonist, antagonist, or mixed agonist/antagonist at the kappa-opioid receptor, $\mathrm{CHO}$ cell membranes that expressed kappa-opioid receptors were incubated with 12 concentrations of nalmefene in the presence of $\left[{ }^{35} \mathrm{~S}\right] \mathrm{GTP} \gamma \mathrm{S}$. Figure $3 \mathrm{c}$ shows 

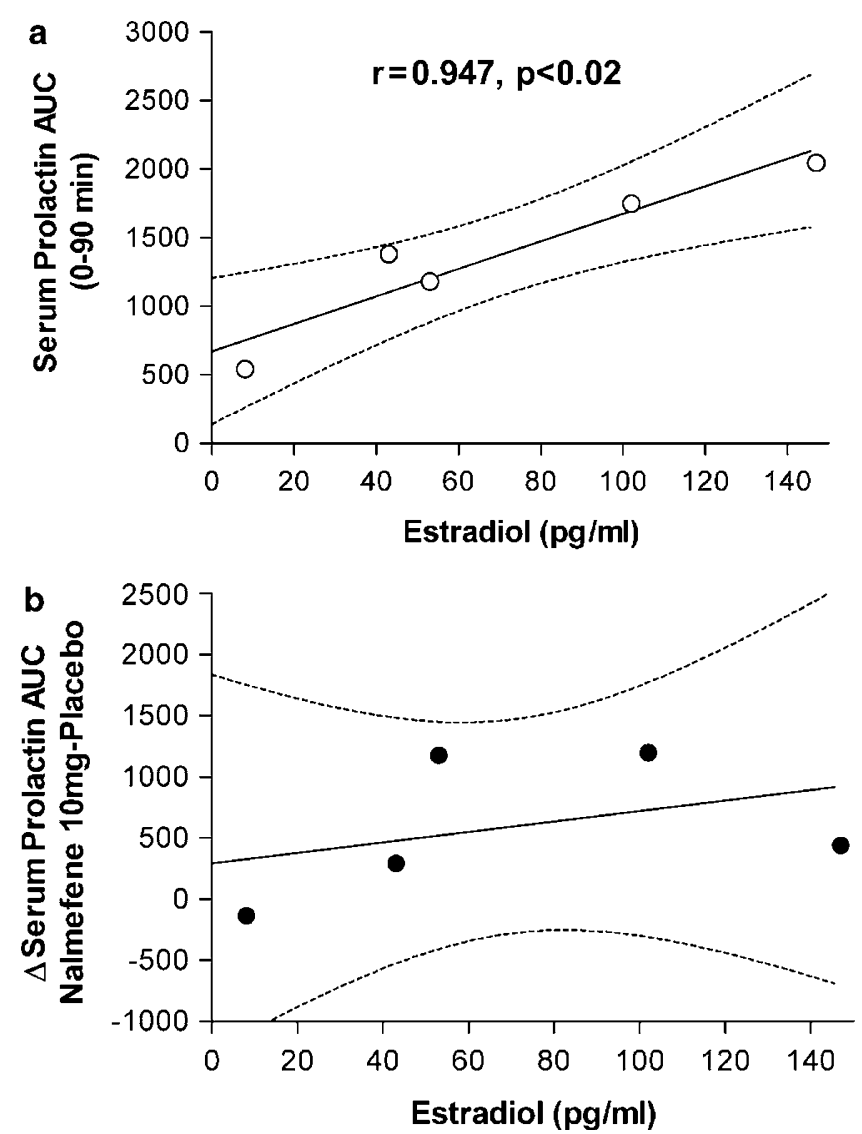

Figure 2 (a) Regression analysis of the effects of basal levels of estradiol in a subset of five women for whom such data was available showed a correlation between basal estradiol and prolactin following placebo of $r=0.947, p<0.02$. (b) There was no correlation between basal estradiol and change in prolactin $A \cup C$ from placebo following nalmefene $10 \mathrm{mg}$.

Table I $K_{\mathrm{i}}$ Values \pm SEM for the Inhibition Mu-, Delta-, and Kappa-Opioid Receptor Binding to $\mathrm{CHO}$ Membranes by Nalmefene

\begin{tabular}{lccc}
\hline Compound & $\begin{array}{c}\mathbf{3}^{\mathbf{3}} \mathbf{H} \text { DAMGO } \\
(\mathbf{m u})\end{array}$ & $\begin{array}{c}\left.\mathbf{}^{\mathbf{3}} \mathbf{H}\right] \text { Naltrindole } \\
\text { (delta) }\end{array}$ & $\begin{array}{c}\left.\mathbf{[}^{\mathbf{3}} \mathbf{H}\right] \mathbf{U 6 9 , 5 9 3} \\
\text { (kappa) }\end{array}$ \\
\hline \multirow{2}{*}{ Nalmefene } & $0.24 \pm 0.006$ & $K_{i}(n M \pm S E)$ & \\
\hline
\end{tabular}

that nalmefene stimulated $\left[{ }^{35} \mathrm{~S}\right] \mathrm{GTP} \gamma \mathrm{S}$ binding, mediated by the kappa-opioid receptor. Nalmefene produced a maximal stimulation, with an $E_{\max }$ value of $29 \pm 1.8 \%$ and had an $\mathrm{EC}_{50}$ value of $4.2 \pm 1.6 \mathrm{nM}$. In addition to producing some agonist effects at the kappa-opioid receptor, nalmefene inhibited $\left[{ }^{35} \mathrm{~S}\right] \mathrm{GTP} \gamma \mathrm{S}$ binding induced by $100 \mathrm{nM} \mathrm{U} 50,488$, as shown in Figure 3d, nalmefene produced maximal inhibition, having an $I_{\max }$ value of $57 \pm 7.3 \%$ and an $\mathrm{IC}_{50}$ value of $18 \pm 1.0 \mathrm{nM}$. These data demonstrate that nalmefene had both agonist and antagonist properties at the kappaopioid receptor.

In summary, nalmefene has very high affinity for mu- and kappa-opioid receptors. It has a three-fold greater affinity for kappa- than mu-opioid receptors, and a 200 -fold greater affinity for kappa- than delta-opioid receptors. In the

$\left[{ }^{35} \mathrm{~S}\right] \mathrm{GTP} \gamma \mathrm{S}$ binding assay, nalmefene had both agonist and antagonist properties that were mediated by the kappaopioid receptor. Nalmefene was an antagonist at mu-opioid receptors.

\section{DISCUSSION}

The results of this study demonstrate that nalmefene is a partial agonist at the human kappa-opioid receptor. This conclusion is supported by increased levels of serum prolactin following nalmefene infusion in healthy human volunteers and by cell binding assays using cloned human kappa-opioid receptors.

Nalmefene is a modestly selective opioid antagonist with affinity for mu-, delta-, and kappa-opioid receptors. In non-human primates and humans, nalmefene's affinity is relatively equivalent at mu- and kappa-opioid receptors followed by delta-opioid receptors. It may, therefore, be difficult to assess in humans what pharmacological effects are specific to nalmefene's kappa activity. While nalmefene may have limited delta-opioid receptor agonist properties (Toll et al, 1998), its affinity at the delta-opioid receptor is very low $\left(K_{\mathrm{i}} \sim 16 \mathrm{nM}\right.$, or 200 -fold less than its affinity at the kappa-opioid receptor) and delta-opioid receptor agonists have not been shown to alter prolactin, the biomarker used in this study (Butelman et al, 2002). It is, therefore, unlikely that delta-opioid receptor effects of nalmefene contributed to our findings and will not be further considered.

\section{Dopamine and the Mu- and Kappa-Opioid Systems}

The mu- and kappa-opioid receptor systems modulate diverse processes including response to pain and analgesia, the stress-responsive hypothalamic-pituitary-adrenal axis (HPA), the hypothalamic-pituitary-gonadal axis, gastrointestinal motility, immune function, and mood. The mu- and kappa-opioid receptor systems also modulate dopaminergic neurons. In rodents, systemically administered mu-opioid receptor agonists stimulate dopamine release in the nucleus accumbens through their inhibition of GABAergic interneurons in the ventral tegmental area (Johnson and North, 1992; Bergevin et al, 2002). GABAergic interneurons in the VTA inhibit dopamine firing in mesolimbic-mesocortical dopaminergic neurons, thus mu-opioid receptor agonists stimulate dopamine release through disinhibition (Di Chiara and Imperato, 1988; Spanagel et al, 1991). Systemically or locally administered synthetic and locally administered natural peptidic kappa-opioid receptor agonists (ie dynorphin) inhibit dopamine release in the mesolimbicmesocortical dopaminergic systems (Di Chiara and Imperato, 1988; Spanagel et al, 1990; Claye et al, 1997; Zhang et al, 2004a, b). While mu- and kappa-opioid receptor antagonists can each reverse these effects, neither administered alone have been shown to alter dopamine release in either rodent or non-human primate models (Deyo et al, 1979; Durham et al, 1996; Butelman et al, 2002). One possible exception is a positron emission tomography (PET) study in rats, which found increased binding potential in the striatum of the displaceable dopamine D1 ligand $\left[{ }^{11} \mathrm{C}\right] \mathrm{SCH} 23,390$ following acute but not chronic nalmefene administration (Unterwald et al, 1997). Interestingly, there was no change in binding 

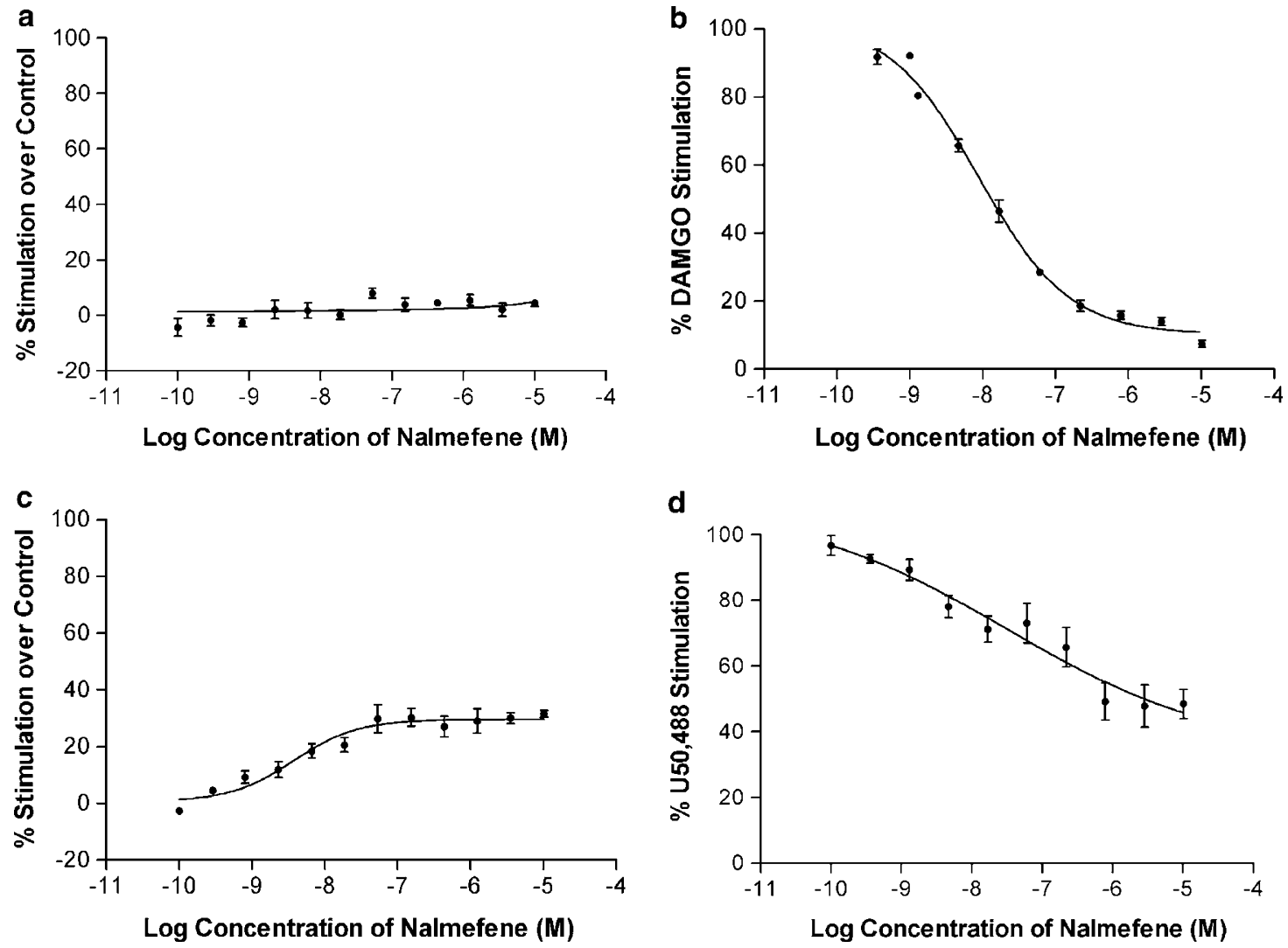

Figure 3 (a) Effect of nalmefene on $\left[{ }^{35} \mathrm{~S}\right] \mathrm{GTP} \gamma \mathrm{S}$ binding mediated by the mu-opioid receptor. Basal activity was determined in the presence of $3 \mu \mathrm{M}$ GDP and in the absence of an agonist, and nonspecific binding was determined in the presence of $10 \mu M$ unlabeled GTP $\gamma$ S. (b) Nalmefene inhibition of $\left.{ }^{35} \mathrm{~S}\right] \mathrm{GTP} \gamma \mathrm{S}$ binding stimulated by DAMGO. DAMGO stimulated $\left[{ }^{35} \mathrm{~S}\right] \mathrm{GTP} \gamma \mathrm{S}$ binding by $102 \pm 1.2 \%$ above basal values. (c) Nalmefene stimulation of $\left.{ }^{35} \mathrm{~S}\right] \mathrm{GTP} \gamma \mathrm{S}$ binding mediated by the kappa-opioid receptor. Basal activity was determined in the presence of $3 \mu \mathrm{M}$ GDP and in the absence of an agonist, and nonspecific binding was determined in the presence of $10 \mu \mathrm{M}$ unlabeled GTP $\gamma \mathrm{S}$. (d) Nalmefene inhibition of $\left.{ }^{35} \mathrm{~S}\right] \mathrm{GTP} \gamma \mathrm{S}$ binding stimulated by $U 50,488$. U50,488 stimulated $\left.{ }^{35} \mathrm{~S}\right] \mathrm{GTP} \gamma \mathrm{S}$ binding by $68 \pm 6.3 \%$ above basal values.

potential of the nondisplaceable dopamine D2 ligand $\left[{ }^{11} \mathrm{C}\right] N$-methylspiperone following either acute or chronic nalmefene.

TIDA neurons, however, are suppressed by both mu- and kappa-opioid receptor agonists. In humans, peripheral administration of the mu-opioid receptor agonist betaendorphin or the kappa-opioid receptor agonist dynorphin A(1-13) will stimulate peripheral levels of serum prolactin (Reid et al, 1981; Kreek et al, 1999). As neither of these peptides has extensive penetrance across the blood-brain barrier, their effects are likely limited to TIDA as opposed to mesolimbic-mesocortical dopaminergic neurons. In humans, dopamine D2 receptors on anterior pituitary lactotrophs act through tonic inhibition from TIDA neurons as the principal modulator of peripheral prolactin release (Durham et al, 1996; Freeman et al, 2000). As kappa-opioid receptors present on presynaptic dopamine terminals and mu-opioid receptors present on GABAergic interneurons inhibit TIDA, serum prolactin also serves as a biomarker for kappa- and mu-opioid receptor agonist activity.

\section{Prolactin and $\mathrm{Mu}-$ and Kappa-Opioidergic Drugs}

There are human data that show both short- and longacting mu-opioid receptor agonists stimulate peripheral levels of prolactin (Kreek, 1978; Ellingboe et al, 1980).
Despite development of tolerance to many of the effects of chronically administered methadone, we have shown that serum prolactin levels increase for 2-4 h following each daily dose in methadone maintained subjects (Kreek, 1978; Bart et al, 2003). In humans, the natural sequence kappaopioid receptor ligand dynorphin $\mathrm{A}(1-13)$ and also synthetic kappa agonists increase serum prolactin (Ur et al, 1997; Kreek et al, 1999; Bart et al, 2003), although the effects following chronic dosing are unknown.

Other than one human study reporting an increase in serum prolactin following intramuscular administration of naloxone $210 \mathrm{mg}$ (Kumor et al, 1988), extensive studies in non-human primates and humans have not found an effect of this mu-opioid receptor antagonist on serum prolactin (Volavka et al, 1980; Morley et al, 1980; Naber et al, 1981; Cohen et al, 1983, 1985; van Bergeijk et al, 1986; VanVugt et al, 1989b). Data for naltrexone and nalmefene, the two antagonists with greater affinity at mu- and kappa-opioid receptors than naloxone, are, however, mixed. One nonhuman primate study found that nalmefene suppressed basal prolactin, whereas its quaternary ammonium form, which does not penetrate the blood-brain barrier, had no effect on prolactin (Simpkins et al, 1991). Another study found that nalmefene had no effect on serum prolactin in male rhesus monkeys (Mello et al, 2000), while another group found that nalmefene stimulated prolactin release in 
normal female rhesus monkeys but not in ovariectomized monkeys (VanVugt et al, 1989b). Naltrexone $50 \mathrm{mg}$ stimulated prolactin release in normal male volunteers, early follicular phase female volunteers, and, following daily dosing for 1 week, in luteal phase female volunteers (Volavka et al, 1979; Mendelson et al, 1986; Gindoff et al, 1988), although, when studied in males, naltrexone $100 \mathrm{mg}$ had no effect on prolactin (Volavka et al, 1979). In an all male study of oral nalmefene $10 \mathrm{mg}$, mean prolactin levels were not different compared to placebo- or naloxonetreated volunteers (Graves et al, 1993). As the current study did not control for menstrual cycle phase and gave nalmefene intravenously, it is difficult to make direct comparisons with the aforementioned studies.

Rodent and non-human primate studies have not shown an effect of kappa-opioid receptor antagonists alone on serum prolactin. We previously found that both naloxone and nalmefene attenuate dynorphin A(1-13)-stimulated increase in serum prolactin in normal human volunteers (Kreek et al, 1999). Interestingly, nalmefene had a greater effect in attenuating dynorphin A(1-13)-induced prolactin release than did an equivalent dose of naloxone. Owing to their unavailability for human use, the effect of kappaopioid receptor selective antagonists on serum prolactin in humans remains unknown.

\section{Mu- and Kappa-Opioid System and Addiction}

The neurobiological effects of drugs of abuse are mediated in part either directly or indirectly by the mu-opioid receptor system. Both rodent and human studies have shown that chronic cocaine and alcohol use lead to altered mu-opioid receptor expression measured as change in levels of mRNA, by quantitative autoradiography, or by PET (Unterwald et al, 1992, 1993, 1994; Zubieta et al, 1996; Yuferov et al, 1999; Bencherif et al, 2004). In mu-opioid receptor knockout mice, opiate self-administration is blocked and both cocaine and alcohol self-administration are attenuated (Roberts et al, 2000; Hall et al, 2001). In addition, several animal models have shown that mu-opioid receptor antagonists will eliminate or curtail alcohol and psychostimulant self-administration and conditioned place preference (Altshuler et al, 1980; Myers et al, 1986; Trujillo et al, 1991; Middaugh and Bandy, 2000).

Chronic cocaine administration has also been shown to increase kappa-opioid receptor expression in rats, a finding also seen in human cocaine overdose deaths (Unterwald et al, 1994; Staley et al, 1997). Natural and synthetic kappaopioid receptor agonists directly infused into the striatum or administered systemically to rodents will both attenuate cocaine-induced dopamine surges in the nucleus accumbens and block cocaine-induced conditioned place preference (Maisonneuve et al, 1994; Zhang et al, 2004a,b). Centrally penetrating kappa-opioid receptor agonists can be aversive in rodents, so studies showing a reduction in alcohol intake but an increased alcohol deprivation effect and a decrease in morphine and cocaine self-administration may be difficult to interpret (Glick et al, 1995; Hölter et al, 2000; Lindholm et al, 2001). Studies of kappa-opioid receptor antagonists have not found an effect of these agents on alcohol, morphine, or cocaine administration (Glick et al, 1995; Hölter et al, 2000).
Acute administration of cyclazocine or butorphanol, compounds with mixed activity at mu- and kappa-opioid receptors, in human cocaine users did not alter the effects of investigator-administered intranasal cocaine or reduce intravenous cocaine self-administration (Walsh et al, 2001; Preston et al, 2004). Enadoline, a selective kappa-opioid receptor agonist, also did not attenuate the effects or selfadministration of intravenous cocaine (Walsh et al, 2001). Chronic treatment with the mixed kappa- and mu-opioid receptor agonist MCL-101, however, did reduce cocaine self-administration in a non-human primate model (Bowen et al, 2003).

A preliminary study on the effects on euphoria of naltrexone in normal volunteers given amphetamine indicates that opioid antagonism may be clinically efficacious in the treatment of amphetamine addiction (JayaramLindström et al, 2004). Other studies also indicate that naltrexone may be useful in the treatment of cocaine addiction (Kosten et al, 1992; Schmitz et al, 2001). There are inadequate studies to delineate whether naltrexone's affinity at kappa-opioid receptors contributes to this and, if so, whether a partial-agonist at kappa-opioid receptors would add further benefit.

Naltrexone is effective in treating some individuals with moderate to severe alcoholism (Volpicelli et al, 1992). While studies of the treatment of alcoholism using nalmefene have been mixed (Mason et al, 1994; Anton et al, 2004), initial studies of nalmefene in the treatment of compulsive gambling have been promising (SW Kim, personal communication). Naltrexone and nalmefene do have comparable affinity at mu- and kappa-opioid receptors. The current study shows, in human and cellular binding studies, that nalmefene acts as a partial agonist at kappa-opioid receptors. It is unclear whether this effect may impart an advantage for the use of nalmefene in the treatment of specific addictive diseases. Using a similar experimental design, it will be important to determine whether the treatment effects of naltrexone may also be related to a partial-agonist effect at kappa-opioid receptors.

\section{ACKNOWLEDGEMENTS}

This work was supported in part by National Institutes of Health (NIH)-National Institute on Drug Abuse (NIDA) Research Scientific Award Grants K05-DA00049 (MJK) and K05-DA00360 (JMB), NIH-NIDA Research Grant P60DA05130 (MJK), and General Clinical Research Center M01-RR00102. We gratefully acknowledge the excellent technical assistance of Brian Knapp and the intellectual contributions of Dr Eduardo Butelman.

\section{REFERENCES}

Altshuler HL, Phillips PE, Feinhandler DA (1980). Iteration of ethanol self-administration by naloxone. Life Sci 26: 679-688.

Anton RF, Pettinati H, Zweben A, Kranzler HR, Johnson B, Bohn MJ et al (2004). A multi-site dose ranging study of nalmefene in the treatment of alcohol dependence. J Clin Psychopharmacol 24: 421-428.

Bart G, Borg L, Schluger JH, Green M, Ho A, Kreek MJ (2003). Suppressed prolactin response to dynorphin $\mathrm{A}_{1-13}$ in methadone 
maintained versus control subjects. J Pharmacol Exp Ther 306: 581-587.

Bencherif B, Wand GS, McCaul ME, Kim YK, Ilgin N, Dannals RF et al (2004). Mu-opioid receptor binding measured by $\left[{ }^{11} \mathrm{C}\right] \mathrm{Car}-$ fentanil positron emission tomography is related to craving and mood in alcohol dependence. Biol Psychiatry 55: 255-262.

Bergevin A, Girardot D, Bourque MJ, Trudeau LE (2002). Presynaptic $\mu$-opioid receptors regulate a late step of the secretory process in rat ventral tegmental area GABAergic neurons. Neuropharmacology 42: 1065-1078.

Bowen CA, Negus SS, Zhong R, Neumeyer JL, Bidlack JM, Mello NK (2003). Effects of mixed-action $\kappa / \mu$ opioids on cocaine selfadministration and cocaine discrimination by rhesus monkeys. Neuropsychopharmacology 28: 1125-1139.

Bradford MM (1976). A rapid and sensitive method for the quantification of microgram quantities of protein utilizing the principle of protein-dye binding. Anal Biochem 72: 248-254.

Butelman ER, Ball JW, Kreek MJ (2002). Comparison of the discriminative and neuroendocrine effects of centrally penetrating $\kappa$-opioid agonists in rhesus monkeys. Psychopharmacology (Berlin) 164: 115-120.

Butelman ER, Harris TJ, Kreek MJ (1999). Apparent efficacy of $\kappa$-opioid receptor ligands on serum prolactin levels in rhesus monkeys. Eur J Pharmacol 383: 305-309.

Chen RZ, Huang RC, Shen CP, MacNeil DJ, Fong TM (2004). Chronic administration of nalmefene leads to increased food intake and body weight gain in mice. Eur J Pharmacol 495: 63-66.

Cheng YC, Prusoff WH (1973). Relationship between the inhibition constant $\left(K_{\mathrm{i}}\right)$ and the concentration of inhibitor which causes 50 percent inhibition $\left(I_{50}\right)$ of an enzymatic reaction. Biochem Pharmacol 22: 3099-3108.

Claye LH, Maisonneuve IM, Yu J, Ho A, Kreek MJ (1997). Local perfusion of dynorphin A1-17 reduces extracellular dopamine levels in the nucleus accumbens. NIDA Res Monogr 174: 113.

Cohen MR, Cohen RM, Pickar D, Kreger D, McLellan C, Murphy DL (1985). Hormonal effects of high dose naloxone in humans. Neuropeptides 6: 373-380.

Cohen MR, Cohen RM, Pickar D, Weingartner H, Murphy DL (1983). High-dose naloxone infusions in normals: dose-dependent behavioral, hormonal, and physiological responses. Arch Gen Psychiatry 40: 613-619.

Deyo SN, Swift RM, Miller RJ (1979). Morphine and endorphins modulate dopamine turnover in rat median eminence. Proc Natl Acad Sci USA 76: 3006-3009.

Di Chiara G, Imperato A (1988). Opposite effects of mu and kappa opiate agonists on dopamine release in the nucleus accumbens and in the dorsal caudate of freely moving rats. J Pharmacol Exp Ther 244: 1067-1080.

Durham RA, Johnson JD, Moore KE, Lookingland KJ (1996). Evidence that D2 receptor-mediated activation of hypothalamic tuberoinfundibular dopaminergic neurons in the male rat occurs via inhibition of tonically active afferent dynorphinergic neurons. Brain Res 732: 113-120.

Ellingboe J, Mendelson JH, Kuehnle JC (1980). Effects of heroin and naltrexone on plasma prolactin levels in man. Pharmacol Biochem Behav 12: 163-165.

Emmerson PL, Liu MR, Woods JH, Medzihradsky F (1994). Binding affinity and selectivity of opioids at mu, delta and kappa receptors in monkey brain membranes. J Pharmacol Exp Ther 271: 1630-1637.

Freeman ME, Kanyicska B, Lerant A, Nagy G (2000). Prolactin: structure, function, and regulation of secretion. Physiol Rev 80: $1523-1631$.

Gindoff PR, Jewelewicz R, Hembree W, Wardlaw SL, Ferin M (1988). Sustained effects of opioid antagonism during the normal human luteal phase. I Clin Endocrinol Metab 66: $1000-1004$.
Glick SD, Maisonneuve IM, Raucci J, Archer S (1995). Kappa opioid inhibition of morphine and cocaine self-administration in rats. Brain Res 681: 147-152.

Graves GR, Kennedy TG, Weick RF, Casper RF (1993). The effect of nalmefene on pulsatile secretion of lutenizing hormone and prolactin in men. Hum Reprod 8: 1598-1603.

Hall FS, Sora I, Uhl GR (2001). Ethanol consumption and reward are decreased in $\mu$-opiate receptor knockout mice. Psychopharmacology 154: 43-49.

Hölter SM, Henniger MSH, Lipkowski AW, Spanagel R (2000). Kappa-opioid receptors and relapse-like drinking in long-term ethanol-experienced rats. Psychopharmacology 153: 93-102.

Jayaram-Lindström N, Wennberg P, Hurd Y, Franck J (2004). Effects of naltrexone on the subjective response to amphetamine in healthy volunteers. J Clin Psychopharmacol 24: 665-669.

Johnson SW, North RA (1992). Opioids excite dopamine neurons by hyperpolarization of local interneurons. J Neurosci 12: 483488.

Kosten T, Silverman DG, Fleming J, Kosten TA, Gawin FH, Compton $\mathrm{M}$ et al (1992). Intravenous cocaine challenges during naltrexone maintenance: a preliminary study. Biol Psychiatry 32: $543-548$

Kreek MJ (1978). Medical complications in methadone patients. Ann NY Acad Sci 311: 110-134.

Kreek MJ, Schluger J, Borg L, Gunduz M, Ho A (1999). Dynorphin A1-13 causes elevation of serum levels of prolactin through an opioid receptor mechanism in humans: gender differences and implications for modulation of dopaminergic tone in the treatment of addictions. J Pharmacol Exp Ther 288: 260-269.

Kumor KM, Haertzen CA, Jasiniski DR, Johnson RE (1988). The psychopharmacologic and prolactin response after large doses of naloxone in man. Pharmacol Biochem Behav 30: 967-975.

Lindholm S, Werme M, Franck J (2001). The selective $\kappa$-opioid receptor agonist $\mathrm{U} 50,488 \mathrm{H}$ attenuates voluntary ethanol intake in the rat. Behav Brain Res 120: 137-146.

Maisonneuve IM, Archer S, Glick SD (1994). U50,488, a $\kappa$ opioid receptor agonist, attenuates cocaine-induced increases in extracellular dopamine in the nucleus accumbens of rats. Neurosci Lett 181: 57-60.

Mason BJ, Ritvo EC, Morgan RO, Salvato FR, Goldberg G, Welch B et al (1994). A double-blind, placebo-controlled pilot study to evaluate the efficacy and safety of oral nalmefene $\mathrm{HCl}$ for alcohol dependence. Alcohol Clin Exp Res 18: 1162-1167.

Mello NK, Mendelson JH, Kelly M (2000). Acute effects of nalmefene on $\mathrm{LH}$, prolactin, and testosterone in male rhesus monkeys. Pharmacol Biochem Behav 66: 275-284.

Mendelson JH, Mello NK, Cristofaro P, Skupny A, Ellingboe J (1986). Use of naltrexone as a provocative test for hypothalamicpituitary hormone function. Pharmacol Biochem Behav 24: 309-313.

Michel ME, Bolger G, Weissman BA (1985). Binding of a new opiate antagonist, nalmefene, to rat brain membranes. Methods Find Exp Clin Pharmacol 7: 175-177.

Middaugh LD, Bandy AL (2000). Naltrexone effects on ethanol consumption and response to ethanol conditioned cues in C57BL/6 mice. Psychopharmacology (Berlin) 151: 321-327.

Morley JE, Baranetsky NG, Wingert TD, Carlson HE, Hershman JM, Melmed S et al (1980). Endocrine effects of naloxoneinduced opiate receptor blockade. J Clin Endocrinol Metab 50: 251-257.

Myers RD, Borg S, Mossberg R (1986). Antagonism by naltrexone of voluntary alcohol selection in the chronically drinking macaque monkey. Alcohol 3: 383-388.

Naber D, Pickar D, Davis GC, Cohen RM, Jimerson DC, Elchisak MA et al (1981). Naloxone effects on beta-endorphin, cortisol, prolactin, growth hormone, HVA and MHPG in plasma of normal volunteers. Psychopharmacology (Berlin) 74: $125-128$ 
NIH Definitions Working Group (2000). Biomarkers and surrogate endpoints in clinical research: definitions and conceptual model. In: Downing GJ (ed). Biomarkers and Surrogate Endpoints: Clinical Research and Applications. Elsevier: Amsterdam.

O'Malley SS, Jaffe AJ, Chang G, Schottenfeld RS, Meyer RE, Rounsaville B (1992). Naltrexone and coping skills therapy for alcohol dependence. A controlled study. Arch Gen Psychiatry 49: 881-887.

O’Malley SS, Krishnan-Sarin S, Farren C, Sinha R, Kreek MJ (2002). Naltrexone decreases craving and alcohol self-administration in alcohol-dependent subjects and activates the hypothalamopituitary-adrenocortical axis. Psychopharmacology 160: 19-29.

Pfeiffer A, Braun S, Mann K, Meyer HD, Brantl V (1986). Anterior pituitary hormone responses to a $\kappa$-opioid agonist in man. J Clin Endocrinol Metab 62: 181-185.

Preston KL, Umbricht A, Schroeder JR, Abreu ME, Epstein DH, Pickworth WB (2004). Cyclazocine: comparison to hydromorphone and interaction with cocaine. Behav Pharmacol 15: 91-102.

Raynor K, Kong H, Chen Y, Yasuda K, Yu L, Bell GI et al (1994). Pharmacological characterization of the cloned kappa-, delta-, and mu-opioid receptors. Mol Pharmacol 45: 330-334.

Reid RL, Hoff JD, Yen SS, Li CH (1981). Effects of exogenous $\beta_{\mathrm{h}^{-}}$ endorphin on pituitary hormone secretion and its disappearance rate in normal human subjects. J Clin Endocrinol Metab 52: $1179-1184$.

Remmers AE, Clark MJ, Mansour A, Akil H, Woods JH, Medzihradsky F (1999). Opioid efficacy in a C6 glioma cell line stably expressing the human kappa opioid receptor. J Pharmacol Exp Ther 288: 827-833.

Roberts AJ, McDonald JS, Heyser CJ, Kieffer BL, Matthes HWD, Koob GF et al (2000). Opioid receptor knockout mice do not self-administer alcohol. J Pharmacol Exp Ther 293: 1002-1008.

San L, Pomarol G, Peri JM, Olle JM, Cami J (1991). Follow-up after a six-month maintenance period on naltrexone versus placebo in heroin addicts. Br J Addict 86: 983-990.

Schmitz JM, Stotts AL, Rhoades HM, Grabowski J (2001). Naltrexone and relapse prevention treatment for cocainedependent patients. Addict Behav 26: 167-180.

Simpkins JW, Swager D, Millard WJ (1991). Evaluation of the sites of opioid influence on anterior pituitary hormone secretion using a quaternary opiate antagonist. Neuroendocrinology 54: 384-390.

Spanagel R, Herz A, Bals-Kubik R, Shippenberg TS (1991). Beta-endorphin-induced locomotor stimulation and reinforcement are associated with an increase in dopamine release in the nucleus accumbens. Psychopharmacology (Berlin) 104: 51-56.

Spanagel R, Herz A, Shippenberg TS (1990). The effects of opioid peptides on dopamine release in the nucleus accumbens: an in vivo microdialysis study. J Neurochem 55: 1734-1740.

Staley JK, Rothman RB, Rice KC, Partilla J, Mash DC (1997). Kappa2 opioid receptors in limbic areas of the human brain are upregulated by cocaine in fatal overdose victims. J Neurosci 17: 8225-8233.

Toll L, Berzetei-Gurske IP, Polagar WE, Brandt SR, Adapa ID, Rodriguez L et al (1998). Standard binding and functional assays related to medications development division testing for potential cocaine and opiate narcotic treatment medications. NIDA Res Monogr 178: 440-466.

Trujillo KA, Belluzzi JD, Stein L (1991). Naloxone blockade of amphetamine place preference conditioning. Psychopharmacology (Berlin) 104: 265-274.
Unterwald EM, Cox BM, Kreek MJ, Cote TE, Izenwasser S (1993). Chronic repeated cocaine administration alters basal and opioidregulated adenylyl cyclase activity. Synapse 15: 33-38.

Unterwald EM, Horne-King J, Kreek MJ (1992). Chronic cocaine alters brain mu opioid receptors. Brain Res 584: 314-318.

Unterwald EM, Rubenfeld JM, Kreek MJ (1994). Repeated cocaine administration upregulates kappa and $\mathrm{mu}$, but not delta, opioid receptors. Neuroreport 5: 1613-1616.

Unterwald EM, Tsukada H, Kakiuchi T, Kosugi T, Nishiyama S, Kreek MJ (1997). Use of positron emission tomography to measure the effects of nalmefene on D1 and D2 dopamine receptors in rat brain. Brain Res 775: 183-188.

Ur E, Wright DM, Bouloux PM, Grossman A (1997). The effects of spiradoline (U-62066E), a kappa-opioid receptor agonist, on neuroendocrine function in man. Br J Pharmacol 120: 781-784. van Bergeijk L, Gooren LJG, van Kessel H, Sassen AM (1986). Effects of naloxone infusion on plasma levels of LH, FSH, and in addition TSH and prolactin in males, before and after oestrogen or anti-oestrogen treatment. Horm Metab Res 18: 611-615.

VanVugt DA, Webb MY, Reid RL (1989a). Comparison of the duration of action of nalmefene and naloxone on the hypothalamic-pituitary axis of the rhesus monkey. Neuroendocrinology 49: 275-280.

VanVugt DA, Webb MY, Reid RL (1989b). Naloxone antagonism of corticotropin-releasing hormone stimulation of prolactin secretion in rhesus monkeys. J Clin Endocrinol Metab 68: 1060-1066.

Volavka J, Bauman J, Pevnick J, Reker D, James B, Cho D (1980). Short-term hormonal effects of naloxone in man. Psychoneuroendocrinology 5: 225-234.

Volavka J, Mallya A, Bauman J, Pevnick J, Cho D, Reker D et al (1979). Hormonal and other effects of naltrexone in normal men. Adv Exp Med Biol 116: 291-305.

Volpicelli JR, Alterman AI, Hayashida M, O'Brien CP (1992). Naltrexone in the treatment of alcohol dependence. Arch Gen Psychiatry 49: 876-880.

Walsh SL, Geter-Douglas B, Strain EC, Bigelow GE (2001). Enadoline and butorphanol: evaluation of $\kappa$-agonists on cocaine pharmacodynamics and cocaine self-administration in humans. J Pharmacol Exp Ther 299: 147-158.

Wehrenberg WB, McNicol D, Wardlaw SL, Frantz AG, Ferin M (1981). Dopaminergic and serotonergic involvement in opiateinduced prolactin release in monkeys. Endocrinology 109: 544-547.

Woods JH, Medzihradsky F, Smith CB, Winger GD, Gmerek DE (1986). Evaluation of new compounds for opioid activity (1985). NIDA Res Monogr 67: 453-489.

Yuferov V, Zhou Y, Spangler R, Maggos CE, Ho A, Kreek MJ (1999). Acute 'binge' cocaine increases mu-opioid receptor mRNA levels in areas of the rat mesolimbic-mesocortical dopamine system. Brain Res Bull 48: 109-112.

Zhang Y, Butelman ER, Schlussman SD, Ho A, Kreek MJ (2004a). Effect of the endogenous $\kappa$ opioid agonist dynorphin A(1-17) on cocaine-evoked increases in striatal dopamine levels and cocaine-induced place preference in C57BL/6J mice. Psychopharmacology 172: 422-429.

Zhang Y, Butelman ER, Schlussman SD, Ho A, Kreek MJ (2004b). Effect of the $\kappa$ opioid agonist R-84760 on cocaine-induced increases in striatal dopamine levels and cocaine-induced place preference in C57BL/6J mice. Psychopharmacology 173: 146-152.

Zubieta JK, Gorelick DA, Stauffer R, Ravert HT, Dannals RF, Frost JJ (1996). Increased mu opioid receptor binding detected by PET in cocaine-dependent men is associated with cocaine craving. Nat Med 2: 1225-1229. 